\title{
PHARMACEUTICAL MARKET OF ANALGESIC MEDICINES IN ROMANIA
}

\author{
IRINA CAZACU ${ }^{1}$, ANNIE FOURRIER-RÉGLAT ${ }^{2}$, FRANÇOISE HARAMBURU ${ }^{3}$, CRISTINA \\ MOGOȘAN $^{1 *}$, SINNZIANA GHEORGHE-CETEAN ${ }^{4}$, OLIVIU VOȘTINARU ${ }^{1}$, FELICIA LOGHIN ${ }^{5}$ \\ ${ }^{I}$ Department of Pharmacology, Physiology and Pathophysiology, Faculty of Pharmacy, "Iuliu Hațieganu” University of \\ Medicine and Pharmacy, 400012, Cluj-Napoca, Romania \\ ${ }^{2}$ Department of Pharmacology, University of Bordeaux, INSERM U657, 33000, Bordeaux, France \\ ${ }^{3}$ Department of Pharmacology, Regional Pharmacovigilance Centre, CHU de Bordeaux, INSERM U657, 33000, Bordeaux, \\ France \\ ${ }^{4}$ Department of General and Inorganic Chemistry, Faculty of Pharmacy, "Iuliu Hațieganu” University of Medicine and \\ Pharmacy, 400012, Cluj-Napoca, Romania \\ ${ }^{5}$ Department of Toxicology, Faculty of Pharmacy, "Iuliu Hațieganu” University of Medicine and Pharmacy, 400012, Cluj- \\ Napoca, Romania
}

*corresponding author: cmogosan@umfcluj.ro

Manuscript received: January 2020

\begin{abstract}
The aim of the present study was to evaluate the pharmaceutical market of analgesic medicines in Romania during 2011 2015. A retrospective descriptive analysis was conducted on sales data provided by IQVIA (formerly IMS Health). Data corresponded to the volume of analgesic sales in hospital and retail pharmacies, split up in units and value (EUR), in prescription only (POM) and over-the-counter (OTC) medication and by region. Data was estimated to cover $95 \%$ of the Romanian market. From 2011 to 2015, the analgesic pharmaceutical market increased by $18.7 \%$ in value and by $6.1 \%$ in units. It was mainly assured by the retail distribution channel (95\%), both for OTC and POM. The highest sales (6.3 units/capita, 12.3 EUR/capita) were found for the capital, Bucharest, while the lowest for counties of the North-East region of Romania (3.5 units/capita, 6.0 EUR/capita). In the context of an increasing analgesic market, programs that promote rational use of these medicines should be a priority at present for the Romanian healthcare system.
\end{abstract}

\section{Rezumat}

Obiectivul studiului a fost evaluarea pieței farmaceutice a medicamentelor analgezice în România în perioada 2011 - 2015. Sa realizat o analiză descriptivă retrospectivă pe baza datelor privind vânzările de medicamente analgezice furnizate de IQVIA (fostă IMS Health). Datele au cuprins volumul vânzărilor de analgezice în farmaciile comunitare și de spital, exprimat în unități standard și valoare (EUR), în funcție de regimul de eliberare a medicamentelor (doar pe bază de prescripție medicală (POM) şi over-the-counter (OTC)) și de regiuni. Estimativ, datele au acoperit 95\% din piața farmaceutică din România. Din 2011 până în 2015, piața farmaceutică a analgezicelor a crescut cu $18,7 \%$ în valoare și cu $6,1 \%$ în unități. A fost asigurată, în principal, de vânzările în farmaciile comunitare (95\%), atât pentru medicamentele POM cât și pentru cele OTC. Cele mai mari vânzări (6,3 unități/locuitor, 12,3 EUR/locuitor) au fost descrise pentru București, iar cele mai mici pentru nord-estul României (3,5 unități/locuitor, 6,0 EUR/locuitor). În contextul unui consum în creștere pentru analgezice, programele care promovează utilizarea rațională a acestor medicamente ar trebui să constituie în prezent o prioritate pentru sistemul de sănătate din România.

Keywords: analgesics, pharmaceutical market, regions, Romania

\section{Introduction}

There are large variances in pharmaceutical sales data between countries and regions, primarily due to their size and the level of development. The lack of data on pharmaceutical sales data, especially for developing countries, hinders the pharmaceutical policy analyses, which are essential in assuring safe, effective and affordable medicines for patients [1].

Analgesic expenditure in a country could be a suggestive indicator of the patterns of pain management. Analgesic medicines have become essential for many health interventions and considerably reduced the burden of pain. Current pain management relies on some classes of medicines, such as opioid analgesics, analgesicsantipyretics and non-steroidal anti-inflammatory drugs (NSAIDs). Other classes occupy an important place in specific pain conditions, such as the triptans for migraine headaches [2].

Information on the analgesic pharmaceutical market in Romania has been made partly available to the general public during the last years mostly through media articles, which contained summaries of data held by companies that provide information, services and technology for the pharmaceutical industry. However, a more detailed analysis has not yet been done. 
Therefore, the objective of the present analysis was to evaluate the pharmaceutical market of analgesic medicines in Romania from 2011 to 2015.

\section{Materials and Methods}

\section{Data extraction}

A retrospective descriptive analysis was performed on the sales data provided by IQVIA (formerly IMS Health) [3]. Data on analgesic medicines were extracted from IMS Health Romania Sell in Sales Territory Audit database for the 2011 - 2015 period.
The names of the active substances were used to quantify analgesic medicines consumption. Analgesics referred to medicines with an approved indication for pain according to the summary of product characteristics and were part of the following classes: opioid analgesics, analgesics-antipyretics, NSAIDs and triptans (Table I). Combinations of active substances, which can be found in certain brand name medicines, were also included. Data were sorted by the channel distribution into hospital and retail expenditure. Sell-in information was provided: it included the transactions between manufacturers or wholesalers and hospital or retailer distributors.

Table I

List of active substances of interest included in the study

\begin{tabular}{|c|c|c|c|}
\hline $\begin{array}{c}\text { N02A } \\
\text { Opioid analgesics }\end{array}$ & $\begin{array}{c}\text { N02B } \\
\text { Analgesics-antipyretics }\end{array}$ & $\begin{array}{c}\text { M01A } \\
\text { NSAIDs }\end{array}$ & $\begin{array}{c}\text { N02C } \\
\text { Triptans }\end{array}$ \\
\hline $\begin{array}{l}\text { Oxycodone } \\
\text { Dihydrocodeine } \\
\text { Morphine } \\
\text { Fentanyl } \\
\text { Pethidine } \\
\text { Nalbuphine } \\
\text { Tramadol } \\
\text { Tapentadol } \\
\text { Oxycodone + naloxone } \\
\text { Codeine + ibuprofen } \\
\text { Codeine + paracetamol } \\
\text { Tramadol + paracetamol }\end{array}$ & $\begin{array}{l}\text { Aspirin } \\
\text { Metamizole } \\
\text { Propyphenazone } \\
\text { Paracetamol } \\
\text { Nefopam } \\
\text { Ziconotide } \\
\text { Aspirin + caffeine } \\
\text { Aspirin + paracetamol + caffeine + chlorpheniramine } \\
\text { Aspirin + paracetamol + caffeine } \\
\text { Aspirin + paracetamol + codeine } \\
\text { Aspirin + ascorbic acid } \\
\text { Aspirin + paracetamol + codeine + caffeine } \\
\text { Metamizole + caffeine + drotaverine } \\
\text { Paracetamol + ibuprofen } \\
\text { Paracetamol + caffeine } \\
\text { Paracetamol + codeine + caffeine } \\
\text { Paracetamol + propyphenazone + caffeine } \\
\text { Paracetamol + propyphenazone + caffeine + codeine } \\
\text { Paracetamol + ascorbic acid } \\
\text { Paracetamol + drotaverine + codeine } \\
\text { Paracetamol + ascorbic acid + codeine }\end{array}$ & $\begin{array}{l}\text { Aceclofenac } \\
\text { Diclofenac } \\
\text { Indomethacin } \\
\text { Ketorolac } \\
\text { Lornoxicam } \\
\text { Ibuprofen } \\
\text { Dexketoprofen } \\
\text { Naproxen } \\
\text { Ketoprofen } \\
\text { Mefenamic acid } \\
\text { Etoricoxib } \\
\text { Parecoxib } \\
\text { Nimesulide } \\
\text { Diclofenac + paracetamol } \\
\text { Diclofenac + orphenadrine } \\
\text { Ibuprofen + codeine }\end{array}$ & $\begin{array}{l}\text { Frovatriptan } \\
\text { Sumatriptan } \\
\text { Rizatriptan } \\
\text { Naratriptan } \\
\text { Eletriptan } \\
\text { Zolmitriptan }\end{array}$ \\
\hline
\end{tabular}

The value of sales was expressed in euro (EUR) and corresponded to the manufacturer's selling price. The manufacturer's selling price or ex-factory price is defined as the price the manufacturer charges for a medicine. In Romania, the external pricing model is used to establish the ex-factory (producer) price for prescription medicines, using 12 European Union (EU) countries as external reference. The wholesaler price has regulated maximal margins starting from the producer price and the pharmacy price has also regulated maximal margins starting from the wholesaler price. There is free pricing for the OTC medicines [4-7].

The volumes of sales were expressed in sales units. The measure available for all forms and dosages was the standard unit, which defines the smallest dose of a product, equivalent to one tablet or capsule, five $\mathrm{mL}$ of a liquid, or one ampoule or vial for an injectable form [8].

According to the dispensing regimen authorized by the Romanian authority, the medicines could be included in one of the two categories: prescription only and non-prescription medicines. Non-prescription medicines, also known as over-the-counter (OTC) medicines, can be found only in pharmacies and dispensed without medical prescription, or can be optionally found on reimbursed medical prescriptions. To assess "per capita" consumption, we used the available data on the size of the Romanian population, by county, from the official web page of National Institute of Statistics [9]. We expressed the results according to the eight regions of economic development in Romania (North-East; South-East; South-Muntenia; South-West-Oltenia; North-West; Centre; BucharestIlfov).

\section{Results and Discussion}

\section{Total analgesic pharmaceutical market}

During 2011 and 2015, the estimated total value of the pharmaceutical expenditure for analgesic medicines in Romania was 716 million EUR for 430 million units. 
As shown in Figure 1, having a steady growth, the market increased by $18.7 \%$ from 131 million EUR in 2011 to 156 million EUR in 2015. The volume of sale units increased by $6.1 \%$ from 85 million units in 2011 to 91 million units in 2015. The volume of units increased steadily during this period, with the exception of 2012 where a slight decrease (3.3\%) was observed compared to 2011. The pharmaceutical market for analgesic medicines was mainly represented by retail market: $95 \%$ of the total market, both in units and value (EUR) (Figure 1).

Retail analgesic pharmaceutical market

There was a $20.5 \%$ increase in the value of the retail market, from 124.2 million EUR in 2011 to 149.6 million EUR in 2015. The increase was constant during the five years. The volume of sales in units also increased during the same period. A $6.3 \%$ increase was observed, from 81 million units in 2011 to 86.1 million units in 2015. The year 2012 was characterized by a $3.5 \%$ decrease in the volume of units compared to 2011 .

\section{Hospital analgesic pharmaceutical market}

An $11.3 \%$ decrease in the hospital market was observed, from 7.1 million EUR in 2011 to 6.3 million EUR in 2015. The decrease was not constant due to a slight $4 \%$ increase of sales in value in 2013, compared to
2012. However, the volume of sales in units remained fairly stable during the five-year period.

OTC analgesic market

The total value of the OTC pharmaceutical market for analgesic medicines in Romania was 357.3 million EUR and the total volume of the market in units was 224.2 million units. The pharmaceutical market for OTC medicines in Romania increased in value by $37.9 \%$ during the five years, from 62 million EUR in 2011 to 85.5 million EUR in 2015. The increase was constant. Except for the year 2012, when there was a $5.7 \%$ decrease, the volume of sales in units also increased from 45.5 million units in 2011 to 47.7 million units in 2015 (a $4.8 \%$ increase).

Prescription analgesic market

The total value of the prescription pharmaceutical market for analgesic medicines in Romania during 2011 - 2015 was 358.6 million EUR and the total volume of the market in units was 205.4 million. A constant increase was observed during 2011-2014 for the value of the market. It increased from 69.3 EUR in 2011 to 76.1 EUR in $2014(9.8 \%)$, and then it decreased by $7.5 \%$ in 2015 . A decrease $(0.5 \%)$ was observed in 2012 compared to 2011. Regarding the volume of sales in units, it showed a $7.8 \%$ increase, from 39.7 million units in 2011 to 42.8 million units in 2015 .

\begin{tabular}{|c|c|c|c|c|}
\hline \multicolumn{5}{|c|}{ Value (mil EUR) } \\
\hline 85.3 & 82.4 & 85.4 & 85.9 & \\
\hline$:-$ & & 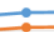 & $\Rightarrow$ & $\rightarrow$ \\
\hline 81.0 & 78.2 & 81.0 & 81.6 & 86.1 \\
\hline 45.5 & 42.9 & 43.5 & 44.3 & 47.7 \\
\hline$\because$ & 20 & $\Rightarrow$ & 0 & $\Rightarrow$ \\
\hline 39.7 & 39.5 & 41.8 & 41.5 & 42.8 \\
\hline 4.2 & 4.2 & 4.3 & 4.2 & 4.3 \\
\hline 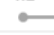 & & 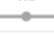 & $\rightarrow$ & $\longrightarrow$ \\
\hline 2011 & 2012 & 2013 & 2014 & 2015 \\
\hline
\end{tabular}

Figure 1.

Evolution of the Romanian analgesic pharmaceutical market in value (mil EUR) - left and in volume (mil standard units) - right, from 2011 to 2015 (based on data provided by IMS Health)

\begin{abstract}
Pharmaceutical expenditure per capita according to regions

The highest expenditure on analgesic medicines in Romania per capita between 2011 and 2015 was found for the capital Bucharest, both in value (12.3 EUR/capita) and units (6.3 units/capita). In terms of value, the capital was followed by counties of the Centre (7.8 EUR/capita) and West Regions (7.6 EUR/ capita) of Romania. Regarding the units, the capital was followed by counties of the West (4.8 units/ capita) and Centre Regions (4.7 units/capita) of Romania. The lowest sales, in value and units, were found for the North-East Region (6.0 EUR/capita, 3.5 units/ capita).
\end{abstract}

The global information and technology services company IMS Health was established in Bucharest in 1994 and collects and reports information within the Romanian pharmaceutical market. Data were collected regularly in the database from wholesalers and were statistically estimated, covering $95 \%$ of the Romanian market (hospital \& retail). In 2016, IMS Health and Quintiles merged to be IQVIA.

Pharmaceutical expenditure is an important tool used in statistics on pharmaceutical markets; its knowledge and development are essential to researchers and policymakers. Large differences can be found among regions and countries, thereby, pharmaceutical expenditure 
can also represent a major indicator for national and international comparisons [4].

The world pharmaceutical market was estimated at 655 billion EUR at ex-factory prices in 2013. Europe's pharmaceutical market (27.4\%) was in second place after the world's largest market North America (41.0\%). The Romanian pharmaceutical market (retail and hospital) was estimated at 2.5 billion EUR in 2011, with an $11.7 \%$ increase compared to 2010, 2.5 billion EUR in 2012, 2.6 billion EUR in 2013, and at 2.7 billion EUR in 2014. The increasing trend of parallel exports, which were estimated at $20-25 \%$ of total sales in Romania, could limit the growth rates of the pharmaceutical market over years. In 2012, pharmaceutical exports for Romania worth 898 million EUR and imports worth 2492 million EUR [9].

In Romania, the index of medicinal products for human use contains around 1360 authorized active substances included in approximately 7350 products, which are available as OTC or prescription medicines [10]. The number of pharmacies in Romania was estimated at around 8300 and the number of hospitals was 499 in 2013 according to the National Institute of Statistics. Ibuprofen is one of the best-selling OTC medicines and metamizole one of the best-selling prescription medicines in Romania [11, 12].

A 2013 IMS Health report on top 20 global therapy areas showed that the global market for pain was in second place after anti-cancer medicines with a $4.7 \%$ growth compared to 2012. The 2014 report ranked global market for pain on the third place after anticancer medicines and antidiabetics, with a $6.5 \%$ increase compared to 2013. Therapy classes defined as pain medication included the following ATC classes: M01A (antiinflammatory and antirheumatic products, non-steroids), M01B (antiinflammatory/antirheumatic agents in combination), M02 (topical products for joint and muscular pain), M03 (muscle relaxants), M05X (drugs for treatment of bone diseases), N01 (anaesthetics) and N02 (analgesics). The sales in these reports covered direct and indirect pharmaceutical channel wholesalers and manufacturers [13, 14].

The present work can be considered the first study attempting to characterize the evolution of analgesic consumption in Romania during 2011 - 2015. The results showed a global increase of analgesic sales in Romania from 2011 to $2015,18.7 \%$ in value and $6.1 \%$ in units, despite a slight decrease in the population during the same time in Romania. The data analysed covered $95 \%$ of the Romanian market. The pharmaceutical analgesic market in Romania from 2011 to 2015 was mainly assured by the retail distribution channel (95\%), both for OTC and prescription medicines. The analgesic market comprised almost equally OTC and prescription medicines, in terms of value and units. Compared to retail market, which showed an increase from 2011 to 2015 for both value $(+20.5 \%)$ and units $(+6.3 \%)$, the hospital market for analgesic medicines decreased in value $(-11.3 \%)$ and had a $2.4 \%$ increase in units during the same period.

A general decline of sales in units was observed for the year 2012. There was also a decrease of the sales in value (EUR) observed for hospital and prescription analgesic market. In Romania, there was a price increase for most medicines between 2011 and 2012, which could have contributed to the decrease in analgesic consumption seen in 2012. In the second trimester of the year 2012, a $2.5 \%$ decrease in the market value in EUR was reported for Romania, compared to the same period in 2011, inflection point which was explained by the tendency of pharmaceutical firms to be focused rather on profitability than on the sales. This was caused by the legislative changes which consisted in the introduction of the claw-back tax on the Romanian market of medicines in October 2011. The $22 \%$ claw-back tax in 2012 was applied to the value of sales of used medicines for each producer. This tax forced the manufacturer to pay a quarterly contribution for reimbursed medicines; if not respected, the medicines for which the payment was not done were excluded from the list of reimbursed medicines [15]. The exposure of Romanian pharmaceutical market to variations in exchange rates could have also impacted the analgesic market. There was a significant depreciation (approximately 10\%) of the Romanian leu (RON) in 2012, from 4.2 up to 4.6 RON/EUR, which negatively impacted the market and the profitability of importers, distributors and retailers [16].

The decline of sales in 2012 influenced the value (EUR) of analgesic market only in hospital settings for prescription medicines. The introduction of electronic prescriptions in Romania in July 2012, each prescription being limited to seven medicines, contributed to an increase in the medical system's transparency, which during precedents years was confronted with some fraud accusations, and to a better and more distinctive healthcare assistance [17].

Factors that contributed to the general increase in prescription analgesic market during the period 2011 2015 could include the lowering of self-medication in Romania, the private health insurance division, which is gaining more and more ground in Romania, and the general amelioration of medicine consumption per capita. In 2017, Romania was the European country with the lowest health expenditure, having a per capita spending of $983 €$ Purchasing Power parity (PPP), compared with the $2773 €$ European PPP average [18]. Factors that led to the growth in the OTC analgesic market could include the increasing use of medicines and the tendency of heading towards the level of European medicines use. The absence of claw-back tax for OTC medicines could have created also a favourable ground for the increase in OTC market. A decline of the sales in units was also observed for the year 2014 for hospital and prescription analgesic market. The sales in value (EUR) decreased in parallel 
in the same year for the hospital analgesic market. A decline in the evolution of the pharmaceutical market in Romania was reported at the beginning of the year 2014 in the first trimester compared to the same trimester of 2013, due to a warmer winter, which could have also influenced in the present analysis the consumption of analgesics-antipyretics and NSAIDs. But the market recovered in the fourth trimester of the year 2014, with an $11.8 \%$ increase compared to the same period in 2013. The year 2014 was also characterized by a general $0.5 \%$ depreciation of the RON currency compared to the previous year, which could have impacted the 2014 analgesic market. At the end of the year 2014 an appreciation of the RON currency against EUR was observed [19].

The highest analgesic expenditure was noted in the South of Romania, which includes the capital Bucharest, followed by the Centre and West Regions. The capital has around $10 \%$ of the Romanian population and is on the first place in terms of economy at national level. The lowest use was reported for the NorthEast Region, which includes counties known as the poorest in Romania [20].

There are several limits of the present work that require careful interpretation of the results. Nevertheless, this analysis is an important insight into the pharmaceutical market of analgesic medicines in Romania during 2011 - 2015. Firstly, the nature of IMS Health sellin data provided for the analysis did not permit achieving a more realistic consumption of analgesic medicines by Romanian patients. For each active substance, due to extraction platform limitations, the products could not be filtered neither according to the pharmaceutical form and dosage, nor indication. Due to the fact that the dosages and the pharmaceutical forms for the active substances were not provided, the calculation of the defined daily dose (DDD) was impeded.

Considering that Romania has one of the lowest prices for medicines in Europe, parallel exports was an important issue affecting the national pharmaceutical market. In the present study, wholesalers trading medicinal products in other European Member states could have impacted the results by obtaining higher numbers for the consumption of medicines at a national level. At present, since 2017 (by Order of the Ministry of Health number 269 since 14 March 2017) there is an obligation to ensure adequate and continuous stocks of medicinal products for wholesalers, but before that, only temporary measures were blocking the export of several medicines [21].

\section{Conclusions}

The Romanian pharmaceutical market for analgesic medicines increased globally from 2011 to 2015, based on data provided by IMS Health. These data also showed the characteristics of the analgesic pharmaceutical market split by Romanian regions, by channel of distribution (hospital or retail) and by the dispensing regimen (OTC and prescription medicines). Data was available in both value (EUR) and units. In this situation of an increasing pharmaceutical market of analgesic medicines in Romania, programs that promote rational use of these medicines should be a priority at present for the Romanian healthcare system.

\section{Acknowledgement}

The statements, findings, conclusions, views and opinions contained and expressed in this analysis are based in part on data obtained under license from the following IQVIA (formerly IMS Health) information service: source: Romania Sell In Sales Territory Audit, January, 2011 - December, 2015, IQVIA (formerly IMS Health). All Rights Reserved. The statements, findings, conclusions, views, and opinions contained and expressed herein are not necessarily those of IQVIA (formerly IMS Health) or any of its affiliated or subsidiary entities.

\section{Conflict of interest}

The authors declare no conflict of interest.

\section{References}

1. Vogler S, Martikainen JE, Drug Utilization Research: Methods and Applications. John Wiley \& Sons, Ltd, Chichester; 2016. Chapter 8, Measurement of drug expenditure: 77-87.

2. Melnikova I, Pain market. Nat Rev Drug Discov., 2010; 9(8): 589-590.

3. IQVIA, IMS Health and Quintiles are now IQVIA, www.iqvia.com/about-us.

4. Vogler S, Zimmermann N, Habl C, Understanding the components of pharmaceutical expenditure-overview of pharmaceutical policies influencing expenditure across European countries. GaBI J., 2013; 2(4): 178187.

5. World Health Organization. Glossary, www.who.int/ medicines/areas/coordination/English_Glossary.pdf.

6. European Pharmaceutical Market Research Association. $6^{\text {th }}$ edition of the EphMRA Lexicon. A guide to Useful pharmaceutical market research terms and definitions, www.ephmra.org/user_uploads/ephmra\%20lexicon $\%$ 206th\%20edition\%20booklet_web.pdf.

7. Kawalec P, Tesar T, Vostalova L, Draganic P, Manova M, Savova A, Petrova G, Rugaja Z, Männik A, Sowada C, Stawowczyk E, Harsanyi A, Inotai A, Turcu-Stiolica A, Gulbinovič J, Pilc A, Pharmaceutical Regulation in Central and Eastern European Countries: A Current Review. Front Pharmacol., 2017; 8: 892: 1-16.

8. Elseviers M, Wettermark B, Almarsdóttir AB, Andersen M, Benko R, Bennie M, Eriksson I, Godman B, Krska J, Poluzzi E, Taxis K, Vlahovic-Palcevski V, Stichele RV, Drug Utilization Research: Methods and Applications, ${ }^{\text {st }}$ Edition, Wiley-Blackwell (Canada), Toronto, 2016; 86. 
9. European Federation of Pharmaceutical Industries and Associations. The pharmaceutical industry in figures, 2014, www.efpia.eu/uploads/ Figures_2014_Final.pdf.

10. National Agency for Medicines and Medical Devices. Index of medicinal products for human use, www. anm.ro/nomenclator/medicamente.

11. The Romanian Health and Pharma Sector 2014. Factor Regional Development Center (FRD Center), www. frdcenter.ro/assets/Romania-Health-and-Pharmamarket-2014DEMO-by-FRD-Center.pdf.

12. Cazacu I, Leucuța DC, Băciuț M, Băciuț G, Mogoșan C, Haramburu F, Fourrier-Réglat A, Loghin F, Acute postoperative pain and analgesics consumption in oral and maxillofacial surgery. Farmacia, 2016; 64(4): 539-543.

13. Lindsley CW, 2013 Statistics for Global Prescription Medications: CNS Therapeutics Maintain a Leading Position among Small Molecule Therapeutics. ACS Chem Neurosci., 2014; 5(4): 250-251.

14. Lindsley CW, 2014 global prescription medication statistics: strong growth and CNS well represented. ACS Chem Neurosci., 2015; 6(4): 505-506.

15. Radu CP, Pana BC, Furtunescu FL, Drug Policy in Romania. Value Health Reg Issues, 2018; 16: 28-32.
16. Romanian pharmaceutical market, report by Roland Berger Strategy Consultants. Romanian Business Digest, http://rbd.doingbusiness.ro/print/romanianpharmaceutical-market-report-by-roland-bergerstrategy-consultants/4853.

17. Health at a Glance: Europe 2010. Pharmaceutical Expenditure. OECD/European Union (2010), OECD Publishing, http://apps.who.int/medicinedocs/ documents/s19849en/s19849en.pdf.

18. Health at a Glance: Europe 2018 State of health in the EU cycle, https://ec.europa.eu/health/sites/health/ files/state/docs/2018_healthatglance_rep_en.pdf.

19. National Romanian Bank. Exchange rates Romanian leu (RON), www.bnr.ro/Exchange-rates-1224.aspx.

20. Savu M, Mindreci G, Development Regions in Romania During the Economic Crisis. Revista Română de Statistică, 2012; 4: 245-248.

21. Order of the Ministry of Health number 269 since 14 March 2017. National Agency of Medicine and Medical Devices, www.anm.ro/_/ORDINE/ORDIN\%20Nr\% 20269\%20din\%2015\%20martie\%202017.pdf. 